\title{
Szakcikk
}

\section{Szomszédsági hatások a világ kukorica piacán 1996 és 2015 között}

\section{SZERB András Bence (iD) 1, FERTő Imre (iD 1,2, CSONKA Arnold (iD 3*}

\author{
${ }^{1}$ Magyar Agrár- és Élettudományi Egyetem, Gazdálkodás- és Szervezéstudományok Doktori Iskola, \\ Kaposvár 7400 Kaposvár, Guba Sándor u. 40. \\ ${ }^{2}$ Közgazdaság- és Regionális Tudományi Kutatóközpont, 1097 Budapest, Tóth K. u. 4. \\ ${ }^{3}$ Magyar Agrár- és Élettudományi Egyetem, Üzleti Szabályozás és Információmenedzsment Intézet, \\ Kaposvári Campus, 7400 Kaposvár, Guba S. u. 40.
}

\section{ABSTRACT - Neighbourhood Effects on the world maize market between 1996 and 2015 (Article)}

Author: $\quad$ András Bence SZERB ${ }^{1}$, Imre FERTŐ ${ }^{1,2}$, Arnold CSONKA ${ }^{3}$

Affiliation: ${ }^{1}$ Hungarian University of Agriculture and Life Sciences, Doctoral School in Management and Organizational Science, Kaposvár, 7400 Kaposvár Guba Sándor u. 40. ${ }^{2}$ Centre for Economic and Regional Studies, 1097 Budapest Tóth K. u. 4. ${ }^{3}$ Hungarian University of Agriculture and Life Sciences, Dpt. of Business Controlling and Information Management, 7400 Kaposvár Guba Sándor u. 40.

The globalization of agriculture has significantly transformed the world trade of maize. The market growth of recent decades, the increase in the number of free trade agreements and territorial concentration justify the study of neighbourhood effects. Although the literature on neighbourhood effects has previously focused almost exclusively on the industrial and service sectors, an examination of the agricultural sectors has also become increasingly common in recent years. The aim of the study is to present spatial dependence as a phenomenon indicating neighbourhood effects in the world maize market between 1996 and 2015. The article analyses spatial dependence in the maize market using Moran's global and local I indicator, covering the effects of temporal dynamics of neighbourhood effects. Our results confirmed that the expansion of the maize market has led to an increase in spatial dependence, mainly limited to only few regions. In the global maize market, we were able to identify the presence of three hot zones in North America, South America, and Europe.

Keywords: agriculture, corn, neighbourhood effect, corn exports

\section{BEVEZETÉS}

Szomszédsági hatás alatt az egymással szomszédos területegységek bizonyos társadalmi-gazdasági folyamatinak, paramétereinek hasonlóságát, együtt mozgását értjük (Nemes Nagy, 2005). Plasztikusabban, Tobler (1970) szavaival élve: „minden összefügg mindennel, de az egymáshoz közelebb eső dolgok szorosabban függenek össze". A téma szakirodalma a közelmúltig elsősorban az ipari és szolgáltatási szektorra koncentrált (Fujita és mtsai, 1999; Cheng és mtsai, 2014; Csuvár és Barna, 2020; de la Mata és Llano-Verduras, 2011) vagy

\footnotetext{
*CORRESPONDING AUTHOR

Magyar Agrár- és Élettudományi Egyetem (MATE), Kaposvári Campus

$\triangle 7400$ Kaposvár, Guba Sándor u. 40., 证 82/502-011; 82/502-020

E-mail: csonka.arnold@uni-mate.hu
} 
egyes országok, régiók vagy ország csoportok gazdaságára (Yang és mtsai, 2017; Combes és Overman, 2004). Az elmúlt években több olyan tanulmány jelent meg, amelyek a szomszédsági hatás jelentőségét igazolják a mezőgazdaság különböző területein is. Kutatások széles köre vizsgálja az agglomerációs és szomszédsági viszonyokat az ökológiai gazdálkodás területén (Allaire és mtsai, 2015; Schmidtner és mtsai, 2012), továbbá azok hatását az ökológiai gazdálkodás terjedését tekintve (Risgaard és mtsai, 2007; Ilbery és Maye, 2010). Kutatásokat találhatunk a témakört illetően a mezőgazdaság további szektoraiban is, például a tejtermelést (Isik, 2004; Mulatu és Wossink, 2014), a sertéshústermelést illetően (Csonka és Fertő, 2017; 2020; Nene és Schoengold, 2019), illetve az agrárerdészet területéről is (Csonka és mtsai, 2018a; 2018b).

A gabonatermékekhez kapcsolódó agglomerációs hatásokat is számos tanulmány elemzi. Neumann és mtsai. (2010) tanulmányukban a gabonatermesztés hatékonyságához és a globális gabonatermelés magasabb hozamaihoz szükséges tényezőket elemezték. Eredményeik szerint a búza, a kukorica és a rizs jelenlegi tényleges hozamai a potenciáljukhoz viszonyítva átlagosan rendre csak 64- 50-, illetve 64 százalékosak.

Holmes és Lee (2012) Észak-Dakotára vonatkozó vizsgálata szerint a szántóföldi növénytermesztés területi koncentrációja mindössze kétharmad részben magyarázható természeti (domborzati, talajminőségi, klíma) adottságokkal, míg egyharmad részben a területi koncentráció agglomerációs és szomszédsági előnyökre vezethető vissza. Sweeney és mtsai. (2013) szerint a Mexikóban tradicionálisnak számító kukorica termesztés a vizsgálati időszak másfél évtizedében jelentős intézményi és gazdasági változásokon ment keresztül. A belső támogatási rendszer és a nemzetközi piaci integrációk következtében az ország USA-val szembeni kukoricaimport-függősége, jelentős növekedésnek indult a 20. század utolsó évtizedében, és ez hatással volt a kukorica termőterületek földrajzi elhelyezkedésére is. McWilliams és Moore (2013) arra a következtetésre jutottak, hogy az Egyesült Államok kukoricaövezetében a kukoricatermesztés területi elhelyezkedését csak részben magyarázzák a természeti előnyök. A térszerkezetre jelentős befolyást gyakorol az export és import piacok földrajzi közelsége. Az eddigi kutatások megerősítik, hogy a mezőgazdaság különböző területein az agglomerációs hatások fontos térszerkezet alakító tényezőként lehetnek jelen.

A globális kukoricaexport területi mintázatát, valamint a szomszédsági viszonyok exportra gyakorolt hatást eddig még nem vizsgálták meg. Tanulmányunkban, első lépésként e hiány pótlására, azt vizsgáljuk, hogy 1996 és 2015 között a világ országainak kukoricaexportjában felfedezhetőek-e szomszédsági hatások, pontosabban szomszédsági hatásokra utaló térbeli függőség. 
A tanulmány a következőképpen épül fel. Először röviden bemutatjuk a globális kukoricapiac fontosabb folyamatait a vizsgált időszakban, majd áttekintést adunk a kutatásunkban használt módszerekről és adatokról. Ezt követően ismertetjük a kutatás főbb eredményeit, továbbá az azokból levonható következtetéseket.

\section{A VILÁG KUKORICAPIACA}

A nemzetközi kukoricapiaci statisztikák azt mutatják, hogy a kukorica teljes vetésterülete 1996 és 2015 között 142 millió hektárról 187 millió hektár fölé emelekedett, ami több mint 31 százalékos növekedést jelent (1. ábra). A vizsgált időszakban a globális piacot meghatározó Egyesült Államok a termőterületét 10 százalékkal növelte, 29 millió hektárról 32 millió hektár fölé. Az EU kukorica termő területe 8,3 millió és 10,4 millió között ingadozott, mindeközben jelentős növekedés volt megfigyelhető a Brazíilia, Oroszország, India, Kína, Dél-Afrikai Köztársaság, azaz a BRICS országcsoport esetében, mely másfélszeresére emelte termőterületét az elmúlt évtizedekben $(F A O, 2020)$.

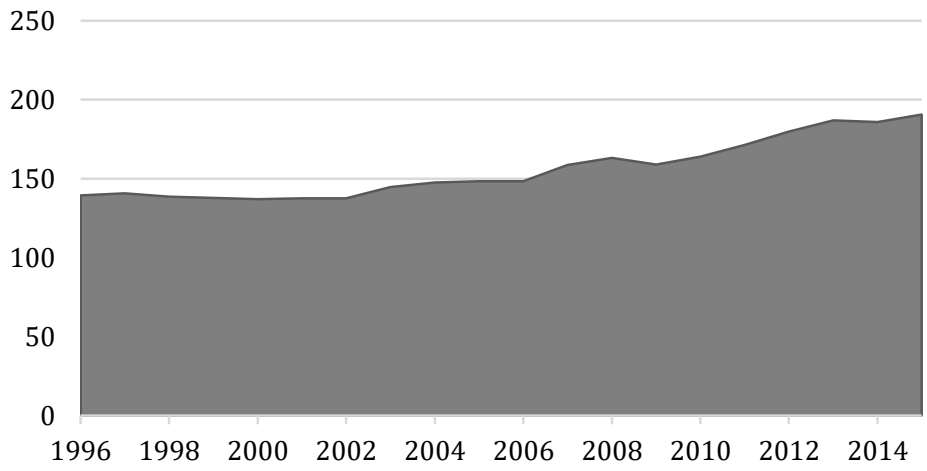

\section{1. ábra}

Kukorica vetésterülete 1996-2015 között (millió hektár) Forrás: Saját számítás FAO (2020) alapján (Figure 1. Maize sown area 1996-2015 (million hectares)

A kukoricahozam tekintetében (tonna/hektár), a folyamatos technológia fejlődésnek és a hatékonyabb növényvédőszer használatnak is köszönhetően, az világátlag emelkedését figyelhetjük meg. Míg 1996-ban 4,19 tonna/hektáros volt a kukorica átlagtermés, addig 2015-ben több mint 30 százalékkal magasabb, 5,53 tonna/hektáros átlagtermést takarítottak be a gazdálkodók ( 2 . 
ábra). Az átlagtermések tekintetében a világpiacot is domináló Egyesült Államok hozamai voltak a legmagasabbak, ám a periódus során a legnagyobb átlaghozam emelkedés a BRICS ország csoport tekintetében volt megfigyelhető (OECD, 2019).

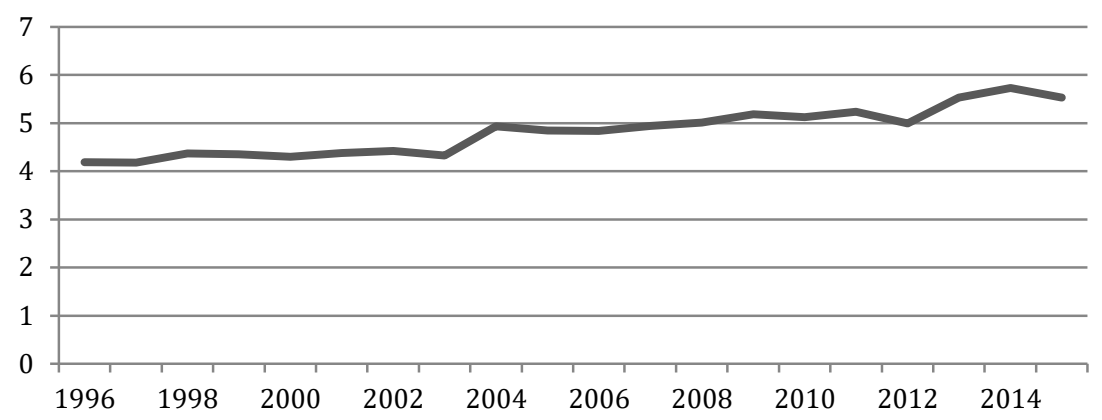

\section{2. ábra}

A világ kukorica hozamainak alakulása a vizsgált periódusban tonna/hektárban. Forrás: Saját számítás OECD (2019) alapján (Figure 2. Development of world maize yields in tonnes / hectare during the study period)

A globálisan rendelkezésre álló készletek jelentősen emelkedtek 1996 és 2015 között. Az OECD (2019) adatai szerint az általunk vizsgál periódus elején a globális termés 600 millió tonna alatt volt, ugyanakkor 2013-tól már folyamatosan meghaladta az 1000 millió tonnát, ami 74\%-os emelkedést jelent, Az Egyesült Államok ezen a területen is tovább növelte dominanciáját, saját készlete 31 százalékkal emelkedett, míg a BRICS országcsoport (Brazília, Oroszország, India, Kína, Dél-Afrika) a vizsgált két évtized során duplájára emelte a rendelkezésre álló készletét. Az Európai Unió 50 és 77 millió tonna közötti készletértéket mutatott.

A kukoricaszektor egy folyamatosan globalizálódó ágazat. A Világbank adatai alapján elmondható, hogy a kereskedelemben is jelentős bővülés volt megfigyelhető a vizsgált periódus két évtizedében. Míg 1996-ban a kukoricaexport értéke alig haladta meg a 12000 millió dollárt, addig 2011-től több alkalommal is átlépte a 40000 millió dolláros forgalmat, ami - igaz, nominális értéken - több mint háromszoros emelkedést jelent a kereskedelem tekintetében ( 3 . ábra). 


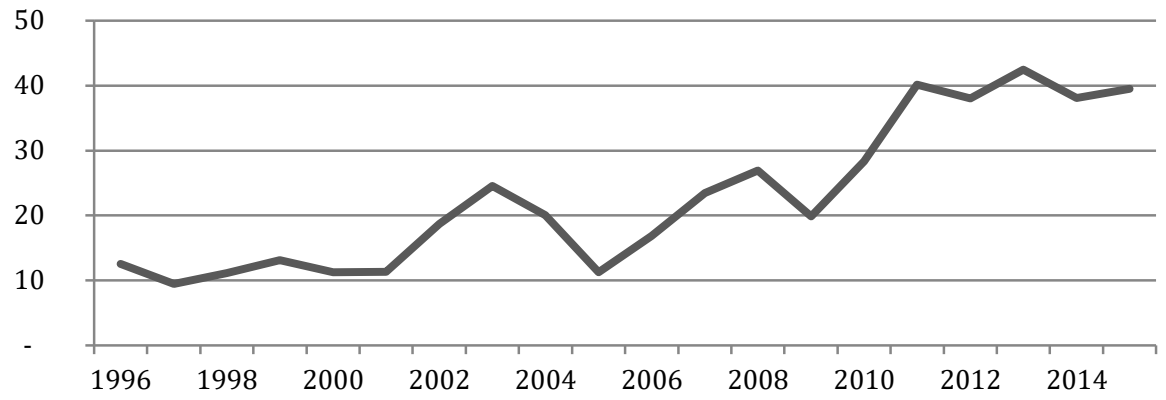

\section{3. ábra}

Globális kukorica kereskedelem alakulása 1996-2015 között (milliárd \$) Forrás: Saját számítás (World Bank, 2017) alapján (Figure 3. Global trade development of maize 1996-2015 (\$ Billion)

\section{ADAT ÉS MÓDSZERTAN}

A kukoricaexport térbeli függőségét több lépésben vizsgáljuk. A térbeli függőség jelenlétét a területi autokorreláció mérésével és tesztelésével vizsgáljuk.

Az autokorreláció mérésére az egyik legelterjedtebb módszert (Tiefelsdorf, 2002), a Moran-féle I mutatót alkalmazzuk. A mutatónak globális és lokális változata van. A globális Moran-féle I méri az összes adatpont között fennálló térbeli autokorrelációt, vagyis azt, hogy a teljes adatkészlet térbeli mintázatára jellemző-e a térbeli függőség (Zhang és mtsai, 2016). A globális Moran-féle I képlete:

$$
I=\frac{\sum_{i=1}^{n} \sum_{j=1}^{n} w_{i j}\left(x_{i}-\bar{x}\right)\left(x_{j}-\bar{x}\right)}{\sum_{i=1}^{n} \sum_{j=1}^{n} w_{i j}\left(x_{i}-\bar{x}\right)^{2}}=\frac{\sum_{i=1}^{n} \sum_{j \neq i}^{n} w_{i j}\left(x_{i}-\bar{x}\right)\left(x_{j}-\bar{x}\right)}{S^{2} \sum_{i=1}^{n} \sum_{j \neq i}^{n} w_{i j}},
$$

ahol n az megfigyelési egységek (országok) számát jelöli, $x_{i}$ és $x_{j}$ az i-edik és j-edik ország éves kukoricaexport-értékének természetes alapú logaritmusát, valamint $w_{i j}$ a sorstandardizált "királynő" típusú szomszédsági súlymátrix i-edik sorban és j-edik oszlopban található eleme. A mátrix elemei két ország szomszédsági kapcsolatát fejezik ki, sorstandardizálás előtti értéküket az alábbi szabály alapján határozzuk meg (Anselin 2010):

$$
\begin{aligned}
& -w_{i j}=1 \text { ha } b n d(i) \cap b n d(j) \neq \varnothing, \\
& -\quad w_{i j}=0, \text { ha } b n d(i) \cap b n d(j)=\varnothing,
\end{aligned}
$$

ahol bnd(i) és bnd(j) rendre az i-edik, valamint j-edik megfigyelési egység (ország) határát alkotó pontok halmazát jelöli. 
A globális Moran-féle I értékkészlete a megfigyelési egységek számától függ, tehát az értéke nem fixen -1 és +1 között mozog, ahogy azt általában a korrelációs együtthatók esetében tapasztaljuk. A globális Moran-féle I értékét a következők szerint értelmezzük (Cliff és Ord,1974):

- $\quad$ I > -1/(n-1) esetében pozitív területi autokorrelációról,

- $\quad$ I $<-1 /(n-1)$ esetében negatív területi autokorrelációról beszélünk,

- $\quad$ I = -1/(n-1) esetben pedig nem beszélhetünk teületi autkorrelációról.

A globális Moran I értékeket a vizsgált időszak (1996-2015) minden évére meghatározzuk.

A lokális Moran-féle I a parciális területi autokorrelációt megfigyelési egységenként méri és teszteli a térbeli függőség mértékét. Használata során arra keressük a választ, hogy egy adott megfigyelési egység kukoricaexportja milyen mértékben korrelál az adott megfigyelési egységgel szomszédos (vele közös határpont/ok/kal rendelkező) egységek kukoricaexportjával. Alkalmazásával azonosíthatjuk a hasonlóan magas, vagy hasonlóan alacsony kukoricaexport-értékekkel bíró országokból álló területi klasztereket.

Az i-edik megfigyelési egység lokális Moran-féle I értékének kiszámítása (Anselin, 1995):

$$
\begin{gathered}
I_{i}=\frac{\left(x_{i}-\bar{x}\right)}{S_{i}{ }^{2}} \sum_{j=1}^{n} w_{i j}\left(x_{j}-\bar{x}\right), \\
S_{i}{ }^{2}=\frac{\sum_{j=1}^{n}\left(x_{j}-\bar{x}\right)^{2}}{n-1}-\bar{x}^{2},
\end{gathered}
$$

ahol $\mathrm{i} \neq \mathrm{j}, \mathrm{x}_{\mathrm{i}}$ és $\mathrm{x}_{\mathrm{j}}$, valamit $\mathrm{w}_{\mathrm{ij}}$ megegyezik a globális Moran-féle I-nél leírt súlymátrix elemeivel.

A szignifikánsan pozitív lokális Moran-féle I értékkel rendelkező országok két típusát különböztethetjük meg, attól függően, hogy átlag feletti, vagy átlag alatti kukorica-export értékkel rendelkeznek:

- High-High (HH) kapcsolatról beszélünk, ha a vizsgált ország és szomszédainak kukoricaexport értéke is átlag feletti;

- Low-Low (LL) kapcsolatról beszélünk, ha a vizsgált ország és szomszédainak kukoricaexport értéke is átlag alatti.

A HH, valamint LL típusú területi egységek a térben egy helyen csoportosulva a térképen is jól kirajzolódó zónákat hoznak létre, amelyeket a szakirodalomban HH-klasztereknek vagy „forró foltoknak” (hotspot), illetve LL-klasztereknek, vagy „hideg foltoknak” (coldspot) is hívnak. 
A szignifikánsan negatív Moran-féle I értékkel rendelkező országokat, kiugró szigetekként, azonosítjuk, hiszen ezek kukoricaexport-értéke felfelé-, vagy lefelé irányban eltér a szomszédok átlagától. Az ilyen országoknak szintén két csoportja különböztethető meg:

- High-low (HL) kapcsolatról beszélünk, ha a vizsgált ország magas értékkel rendelkezik egy jellemzően alacsony értékű szomszédsági környezetben;

- $\quad$ Low-high (LH) kapcsolatról beszélünk, ha a vizsgált ország alacsony értékkel bír egy jellemzően magas értékű szomszédsági környezetben.

A területi autokorrelációs klasztereket és kiugró szigeteket a táblázatba foglalva, majd a múltbéli teljesítmény hatását az adott évre a GeoDa 1.14.0 szoftver segítségével készült LISA/local Moran I térképeken mutatjuk be. A LISA jelen esetben a Local Indicatora of Spatial Assocation rövidítése. Terjedelmi okokból a LISA-térképek közül a 2001-ra, 2006-re, 2011-re és 2015-re vonatkozókat mutatjuk be.

A globális és lokális Moran-féle I becslésekor a pseudo-p 1 százalék alatti értékét tekintjük szignifikánsnak, a pseudo-p érték meghatározása 9999 permutáció alapján történik.

A tanulmányban az 1996 és 2015 közötti időszakot vizsgáljuk. Az exportadatok az ENSZ Comtrade adatbázisából (UNSD, 2017), a World Integrated Trade Solution (WITS) adatbázisból és szoftveréből (amerikai dollárban denominált) (The World Bank, 2017) származnak. Az empirikus elemzés a kukorica kétoldalú kereskedelmén alapul a Harmonizált rendszer 4 számjegyű szintjén (HS1005 kód).

\section{EREDMÉNYEK}

A kukoricaexport globális autokorrelációja 1997 és 2000 között a jelentősen, közel harmadára csökkent (1. táblázat). A Moran-féle I érték ezután sem tért vissza a korábbi, magasabb szintre, viszonylag nagy kilengésekkel 0,108 és 0,349 között ingadozott. Ezek az értékek gyenge, azonban minden évben szignifikáns térbeli autokorrelációt mutatnak. A térbeli függőség tehát jelen van a nemzetközi kukoricakereskedelemben, ennek mértéke azonban alacsony és időben instabil, ingadozó. Ez az alacsony térbeli függőség arra utal, hogy az egyes országok kukoricaexportját sokkal inkább az egyéb gazdasági, társadalmi és természeti összefüggések határozzák meg, és csak kisebb mértékben a szomszédsági viszonyok. Ez összhangban van a gravitációs kereskedelmi 
modellekben is vizsgált ténnyel, miszerint a globalizálódó gazdasági térben jelentősen csökken a földrajzi távolsággal összefüggő tranzakciós (főként szállítási) költségek bilaterális kereskedelemi kapcsolatokra gyakorolt hatása (Yotov, 2012; Lin és Sim, 2012; Yilmazkuday, 2020).

Fontos megjegyezni, hogy a térbeli függőség mértékének változásai nem kötődnek sem a vetésterület, sem a termelési mennyiség, sem az exportvolumen trendjeihez. A Moran-féle I legnagyobb változása éppen abban az időszakban történt, amikor mind a termelés, mind a globális kereskedelem stagnált. A termelés és a kereskedelem radikális növekedési időszaka alatt ugyanakkor a Moran-féle I trend nélküli ingadozása volt jellemző.

\section{1. táblázat}

A globális Moran-féle I alakulása az országok közötti kukoricakereskedelemben 1996 és 2015 között

\begin{tabular}{llllllllllll}
\hline Év & 1996. & 1997. & 1998. & 1999. & 2000. & 2001. & 2002. & 2003. & 2004. & 2005. \\
\hline Moran's I & 0,239 & 0,349 & 0,198 & 0,17 & 0,132 & 0,214 & 0,145 & 0,111 & 0,178 & 0,171 \\
\hline Év & 2006. & 2007. & 2008. & 2009. & 2010. & 2011. & 2012. & 2013. & 2014. & 2015. \\
\hline Moran's I & 0,157 & 0,141 & 0,217 & 0,224 & 0,163 & 0,113 & 0,108 & 0,142 & 0,179 & 0,207
\end{tabular}

Megjegyzés: mindegyik év szignifikancia szintje: pseudo $\mathrm{p}<0,01$.

Table 1. Evolution of global Moran I in corn trade between countries between 1996 and 2015

Figyelemre méltó a térbeli függőség és a piaci növekedés egymástól független viselkedése, ha arra gondolunk, hogy 2004-től kezdődően nem csupán bővült a kukoricapiac, hanem jelentős változások voltak tapasztalhatóak a különböző régiók kereskedelmében is (pl. a BRICS-országok előretörése a termelésben és exportban). Másképpen fogalmazva: a kukoricaexport térbeli struktúrájában voltak jelentős változások, azonban ez nem okozott elmozdulást a térbeli függőség mértékében. A piaci növekedés jórészt kereskedelmi kapcsolatok már korábban már meglévő területi mintázata mentén ment végbe.

A globális területi autokorreláció gyenge, de folyamatosan pozitív és szignifikáns arra utal, hogy a kukoricaexport országok közötti megoszlását tekintve létezhetnek olyan területi (HL és LL) klaszterek, zónák, amelyeken belül az egymással szomszédos országok hasonló export intenzitással rendelkeznek.

A 2. táblázatban foglaltuk össze a szignifikánsan pozitív (High-high, Lowlow) és szignifikánsan negatív (High-low, Low-high) lokális Moran-féle I értékkel rendelkező országok csoportjait a vizsgálati periódus évtizedéből öt évet 
kiemelve. A táblázat I. sorba a szignifikáns HH kapcsolattal jellemezhető országokat tartalmazzák a cellák, a II. sor a szignifikáns LL kapcsolattal bíró államok találhatók, a III. szomszédokat alulmúló LH „szigetek”, a IV. a szomszédokat meghaladó értékkel bíró HL „szigetek vannak jelölve. Mivel a táblázat eredményi közül jelentőségét és az országok számát tekintve is kiemelkedik az I. (high-high) zóna, ezért ebben a sorban kontinensenkénti bontásban szerepeltetjük az országokat.

A 2. táblázat adatai szerint három zóna rajzolódik ki. Az Észak-Amerikában az Egyesült Államok és Kanada alkot egy nagy kiterjedésű „forró zónát”, Mexikó a periódus közepétől mutatott szignifikáns kapcsolatot a szomszédaival. A 2006-os évben az Egyesült Államok nem szignifikáns szomszédsági kapcsolatokkal bíró országok között szerepel. Ennek elsődleges okát az Egyesült Államok extrém magas kukoricaexport értékében, az egész világon egyedülálló exportdominanciájában látjuk. Ez alapján az Egyesült Államoknak egy „kiugró” HL szigetnek kellene lennie, ugyanakkor arról is írtunk, hogy közvetlen szomszédai is igen aktív szereplői a kukoricapiacnak. Az Egyesült Államok tehát része is a zónának, ugyanakkor exportvolumene kiemelkedik a szomszédos országok sorából. Ez magyarázhatja a lokális Moran-féle I nem szignifikáns értékét a szóban forgó évben. Az Észak-Amerikai klaszter stabil jelenléte tükrözi a NAFTA (Észak-Amerikai Szabadkereskedelmi Egyezmény) pozitív hatását a térség országai közötti kukoricakereskedelemre (Schnepf, 2007; Ackerman és mtsai, 2003; Zahniser és Coyle, 2004).

Dél-Amerika is forró zónaként írható le. Minden évben találunk a táblázat soraiban olyan országot, amely a kontinensen található, és a klasztert alkotó országok száma is stabil volt a vizsgált időszak során. A lokális autokorreláció ebben az esetben is csak részben a valódi klasztermagra szignifikáns, hiszen Argentína a teljes periódus során szignifikáns értéket mutat (véleményünk szerint azonban Brazília is ilyen szerepet tölthet be). A klasztermaggal szomszédos, kisebb exportvolumennel rendelkező országok (Bolívia, Chile, Paraguay, Peru Uruguay) stabilan a forró zónához tartoznak Uruguay kivételével 2006-ban és Chile kivételével 2011-ben.

Igazán látványos átalakulást figyelhetünk meg az európai forró zóna esetében. 1996-ban még nem is beszélhetünk valódi, összefüggő zónáról: szignifikáns HH kapcsolattal mindössze néhány ország, Ausztria, Dánia, Magyarország, Moldova, Olaszország, Szlovákia, Svájc és Ukrajna rendelkezett. Az ezredfordulót követően azonban a kontinensen kialakult egy lényegesen nagyobb klaszter, amely Nyugat és Közép-Európa országait foglalta magában. Az említett országok mellett Belgium, Csehország, Franciaország, Hollandia, Luxemburg, Németország, Portugália és Románia alkották a zónát (Ukrajna kivételével). 


\section{2. táblázat}

Országcsoportok a kukoricaexport lokális Moran I-értéke szerint (1996-2015)

\begin{tabular}{|c|c|c|c|c|c|}
\hline \multirow{2}{*}{$\begin{array}{l}\text { Autokor- } \\
\text { relációs } \\
\text { zónák }\end{array}$} & \multicolumn{5}{|l|}{ Év } \\
\hline & 1996 & 2001 & 2006 & 2011 & 2015 \\
\hline $\begin{array}{l}\text { I. (High- } \\
\text { High) }\end{array}$ & $\begin{array}{l}\text { Észak- és Kö- } \\
\text { zép-Amerika: } \\
\text { Kanada*** } \\
\text { Egyesült Álla- } \\
\text { mok** } \\
\text { Dél-Amerika: } \\
\text { Argentína* } \\
\text { Bolívia** } \\
\text { Chile* } \\
\text { Paraguay** } \\
\text { Peru* } \\
\text { Uruguay** } \\
\text { Európa: } \\
\text { Ausztria* } \\
\text { Dánia* } \\
\text { Magyarország* } \\
\text { Moldova* } \\
\text { Olaszország* } \\
\text { Svájc*** } \\
\text { Szlovákia* } \\
\text { Szlovénia** } \\
\text { Ukrajna* } \\
\text { Afrika, Ázsia: } \\
\text { Kambodzsa* } \\
\text { Laosz** } \\
\text { Nepál* }\end{array}$ & $\begin{array}{l}\text { Észak- és Közép- } \\
\text { Amerika: } \\
\text { Kanada*** } \\
\text { Dél-Amerika: } \\
\text { Argentína** } \\
\text { Bolívia*** } \\
\text { Chile* } \\
\text { Paraguay*** } \\
\text { Peru** } \\
\text { Uruguay*** } \\
\text { Európa: } \\
\text { Ausztria** } \\
\text { Belgium* } \\
\text { Csehország* } \\
\text { Dánia* } \\
\text { Franciaország** } \\
\text { Hollandia* } \\
\text { Luxemburg** } \\
\text { Magyarország* } \\
\text { Moldova* } \\
\text { Németország** } \\
\text { Olaszország** } \\
\text { Portugália* } \\
\text { Románia* } \\
\text { Svájc*** } \\
\text { Szlovákia** } \\
\text { Szlovénia** } \\
\text { Afrika, Ázsia: } \\
\text { Kambodzsa* } \\
\text { Laosz** } \\
\text { Nepál** } \\
\text { Hong Kong** }\end{array}$ & 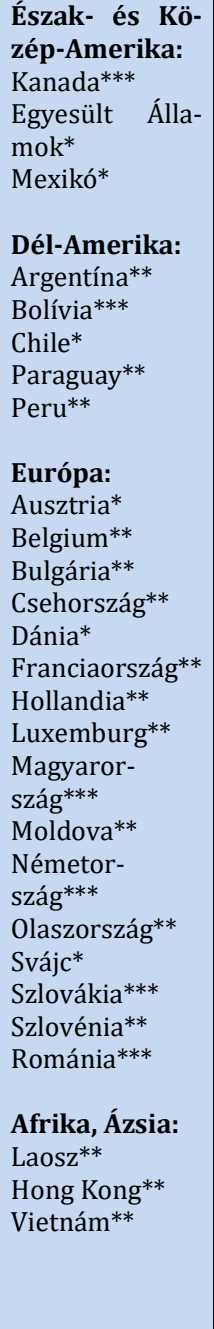 & $\begin{array}{l}\text { Észak- és Kö- } \\
\text { zép-Amerika: } \\
\text { Kanada*** } \\
\text { Egyesült Álla- } \\
\text { mok* } \\
\text { Mexikó* } \\
\text { Dél-Amerika: } \\
\text { Argentína* } \\
\text { Bolívia** } \\
\text { Paraguay** } \\
\text { Uruguay*** } \\
\text { Európa: } \\
\text { Ausztria** } \\
\text { Belgium** } \\
\text { Bulgária** } \\
\text { Csehország** } \\
\text { Franciaország* } \\
\text { Hollandia* } \\
\text { Horvátország* } \\
\text { Luxemburg** } \\
\text { Lengyelor- } \\
\text { szág** } \\
\text { Magyaror- } \\
\text { szág*** } \\
\text { Moldova** } \\
\text { Németor- } \\
\text { szág*** } \\
\text { Olaszország* } \\
\text { Románia*** } \\
\text { Szerbia* } \\
\text { Szlovákia*** } \\
\text { Szlovénia** } \\
\text { Ukrajna** } \\
\text { Afrika, Ázsia: } \\
\text { Mozambik** } \\
\text { Tanzánia* }\end{array}$ & $\begin{array}{l}\text { Észak- és Kö- } \\
\text { zép-Amerika: } \\
\text { Kanada*** } \\
\text { Egyesült Álla- } \\
\text { mok* } \\
\text { Mexikó* } \\
\text { Dél-Amerika: } \\
\text { Argentína** } \\
\text { Bolívia*** } \\
\text { Chile* } \\
\text { Paraguay ** } \\
\text { Peru* } \\
\text { Uruguay*** } \\
\text { Európa: } \\
\text { Ausztria** } \\
\text { Belgium** } \\
\text { Bulgária** } \\
\text { Csehország** } \\
\text { Franciaor- } \\
\text { szág* } \\
\text { Horvátország* } \\
\text { Hollandia* } \\
\text { Lengyelor- } \\
\text { szág* } \\
\text { Luxemburg** } \\
\text { Magyaror- } \\
\text { szág*** } \\
\text { Németor- } \\
\text { szág*** } \\
\text { Moldova** } \\
\text { Olaszország* } \\
\text { Románia*** } \\
\text { Szerbia* } \\
\text { Szlovákia*** } \\
\text { Szlovénia** } \\
\text { Ukrajna*** } \\
\text { Afrika, Ázsia: } \\
\quad-\end{array}$ \\
\hline
\end{tabular}




\begin{tabular}{|c|c|c|c|c|c|}
\hline \multirow{2}{*}{$\begin{array}{l}\text { Autokor- } \\
\text { relációs } \\
\text { zónák }\end{array}$} & \multicolumn{5}{|l|}{ Év } \\
\hline & 1996 & 2001 & 2006 & 2011 & 2015 \\
\hline $\begin{array}{l}\text { II. (Low- } \\
\text { Low) }\end{array}$ & $\begin{array}{l}\text { Irán* Irak** } \\
\text { Szenegál* Gui- } \\
\text { nea-Bissau* }\end{array}$ & $\begin{array}{l}\text { Irak* Algéria** Ni- } \\
\text { ger* Palesztina* }\end{array}$ & $\begin{array}{l}\text { Guinea-Bissau* } \\
\text { Szenegál** }\end{array}$ & $\begin{array}{lr}\text { Irán* } & \text { Kame- } \\
\text { run* } & \text { Kuvait* } \\
\text { Katar* } & \end{array}$ & $\begin{array}{l}\text { Irak* Algéria* } \\
\text { Libanon* Ka- } \\
\text { tar** Svédor- } \\
\text { szág** }\end{array}$ \\
\hline $\begin{array}{l}\text { III. } \\
\text { (Low- } \\
\text { High) }\end{array}$ & $\begin{array}{lr}\text { Bhután* } & \text { Bel- } \\
\text { gium* } & \text { Le- } \\
\text { sotho** } & \text { Taj- } \\
\text { van** } & \end{array}$ & $\begin{array}{l}\text { Bhután** Le- } \\
\text { sotho** Tajvan** } \\
\text { Mozambik }^{* *}\end{array}$ & $\begin{array}{ll}\text { Bhután** } & \text { Le- } \\
\text { sotho* } & \text { Tajvan** } \\
\text { Nepál** } & \text { Uru- } \\
\text { guay*** }^{*} & \text { Bangla- } \\
\text { des* }^{*} \text { Fehér- } \\
\text { oroszország* }\end{array}$ & $\begin{array}{l}\text { Bhután* Le- } \\
\text { sotho** Nepál* } \\
\text { Svájc** } \\
\text { des** Fangla- } \\
\text { oroszország** } \\
\text { oro }\end{array}$ & $\begin{array}{l}\text { Lesotho* } \\
\text { Svájc** Bang- } \\
\text { lades* Fehér- } \\
\text { oroszország** } \\
\text { Mozambik* }\end{array}$ \\
\hline $\begin{array}{l}\text { IV. } \\
\text { (High- } \\
\text { Low) }\end{array}$ & $\begin{array}{l}\text { Kongói DK* Ko- } \\
\text { rea*** Mali** } \\
\text { Malawi** } \\
\text { Szaúd-Arábia** }\end{array}$ & $\begin{array}{|lr|}\text { Korea*** } & \text { Szaúd- } \\
\text { Arábia* } & \text { Szene- } \\
\text { gál*** } & \text { Egyiptom* } \\
\text { Nigéria** } & \text { Szíria* } \\
\text { Tunézia*** } & \\
\text { Uganda* } & \text { Burkina } \\
\text { Faso** } & \end{array}$ & $\begin{array}{l}\text { Korea*** Mali** }^{* *} \\
\text { Egyiptom** Ni- } \\
\text { géria* }\end{array}$ & 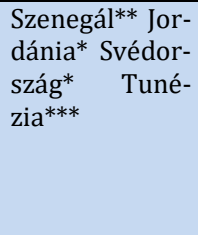 & $\begin{array}{ll}\text { Izrael* }^{*} & \text { Jordá- } \\
\text { nia** } & \text { Tuné- } \\
\text { zia** }^{*} & \\
\end{array}$ \\
\hline
\end{tabular}

Megjegyzés: szignifikancia szintek ${ }^{* * *} \mathrm{p}<0,01 ;{ }^{* *} 0,01=<\mathrm{p}<0,05 ;{ }^{*} 0,05=<\mathrm{p}<0,1$

Table 2. Country groups according to the local Moran I value of maize exports (1996-2015)

2006-tól ez az európai klaszter folyamatosan keleti irányba tolódott, amely először Portugália, majd Svájc, klaszterből való kiesését, míg 2006-tól Bulgária, 2011-től pedig Lengyelország, Horvátország és Szerbia megjelenését, illetve Ukrajna klaszterbe való visszakerülését jelentette. Kétségkívül ez a folyamat képezte a legdinamikusabb földrajzi átrendeződést a globális kukoricapiacon a vizsgált periódus során.

A látványosan előre törő ázsiai országok (India, Kína, és ebből a szempontból most idesoroljuk Oroszországot is) kukoricaexportjának bővülése a vizsgált időszak alatt nem eredményezte a velük szomszédos országok bevonását a kukoricapiacra. Mindhárom idesorolt állam vezető kukoricaexportőrré válásukból a térség más szereplői, legalábbis a szomszédsági hatásokon keresztül nem profitáltak. Ázsiai HH ország szerepét a periódus első felében mindössze két ország, Laosz és Nepál töltötték be időszakosan.

Jelentős LL zónák, azaz hideg foltok és kisebb zónák elvétve alakultak ki, elsősorban az Arab-félszigeten és a Perzsa-öböl országiban. 1996-ban Irán és Irak, majd Irak és Palesztina voltak LL országok. 2011-ben A Perzsa-öböl számos országa (Irán, Kuvait, Katar), míg 2015-ben Irak, Katar és Libanon voltak a régió LL országai. Jelen esetben LL országok, kialakulása mögött feltételezhetően természeti, klimatikus adottságok mellett, esetleges lokális fegyveres 
konfliktusok is állhatnak. Nyugat-Afrikában találhatunk az időszak első felében egy LL klasztercsoportot, amelyet Szenegál és Bissau-Guinea alkottak. Kizárólag az utolsó vizsgált évben emelhető ki a Skandináv országok közül Svédország, mint LL ország, feltételezhetően természeti és klimatikus viszonyok miatt.

A vizsgált periódus két évtizedében szinte minden kontinensen találhatók olyan országok, amelyek exportja lefelé irányban tér el a szomszédaitól. Lesotho az egyetlen ország, amely a teljes periódus során ebbe a kategóriába tartozik. Tajvan 2006-ig, Buthán 2011-ig sorolható ebbe a klaszterbe. Elsősorban magas értékű szomszédsági környezet miatt látjuk ideiglenesen feltűnni a délamerikai klaszter forró zónájában elhelyezkedő Uruguayt a 2006-os évben. Az európai országok közül a vizsgálati időszak második felétől Fehéroroszország, majd Svájc is a LH kategóriába sorolóik. E két ország elsősorba a korábban már említett közép-kelet európai forró zóna kialakulása miatti magas exportértékkel rendelkező szomszédok miatt kerülhetett ebbe a kategóriába.

A HL országok kialakulása a vizsgált időszakban csak sziget-szerűen következett be, elsősorban Afrika különböző térségeiben, az Arab-félszigeten és Ázsia keleti parvidékein.

A 3. ábrán azt kívánjuk bemutatni, hogy adott ország exportjára milyen hatással van a szomszéd országok öt évvel korábbi exportja, azaz a múlt hogyan befolyásolta a jelent. A múltban keresendő hatások vizsgálatához a vizsgálati időszak két évtizedes periódusát négy szakaszra osztva értékeltük. Piros színnel (High-high) láthatók azok az országok, ahol a szomszédok öt évvel korábbi exportja szignifikánsan pozitívan befolyásolta az adott ország későbbi exportját. A korábban már említett forró zónák, ebben a vizsgálatban is kirajzolódni látszanak. Észak-Amerika esetében Kanada, Mexikó és az Egyesült Államok kukoricaexport aktivitására hatással volt a szomszédok korábbi exportteljesítménye is. Dél-Amerika esetében Argentína, Paraguay, Bolívia, Chile, Peru és 2001-ben Brazília esetében is elmondhatjuk, hogy a kukoricaexport szomszédsági hatásának időbeli dinamikája is kimutatható a kontinensen. Európa esetében jól látható az exportpiacok időbeli szomszédsági vizsgálatakor a HH országok keleti irányba tolódása a vizsgálati időszak során az Atlanti-óceántól (Franciaországtól) egészen a Fekete-tengerig (Ukrajnáig). A dél-kelet ázsiai régióban Nepál és Laosz exportjára volt pozitív hatással a szomszédok korábbi export teljesítménye 2001-ben és 2006-ban. Az afrikai kontinens dél-keleti részén a periódus második felében alakult ki egy kisebb régió Mozambik és Tanzánia részvételével, melyre pozitív hatással volt a szomszédok korábbi exportteljesítménye. 
Kék színnel azok a sziget-szerűen kialakult országok és régiók vannak jelölve, ahol a szomszéd negatív múltbeli exportteljesítménye az adott ország jelenbeli exportjára is negatív hatással van. Ilyen országok időszakos feltűnése a térképen elsősorban az Arab-félszigeten találhatók (Irak, Kuvait), illetve Nyugat-Afrikában (Mali, Niger, Szenegál, Kamerun).

Eredményeink arra utalnak, hogy a szomszédsági hatások időbeli dinamikával is rendelkeznek, vagyis egy adott ország kukoricaexportját a szomszéd országok jelenlegi piaci aktivitásán kívül, azok múltbéli exporttevékenysége is befolyásolja.

\section{KÖVETKEZTETÉSEK}

Tanulmányunkban megvizsgáltuk, hogy a világ országainak kukoricaexport aktivitásában felfedezhető-e térbeli függőség az 1996 és 2015 közötti időszakban, amely a szomszédsági hatások jelenlétére utal. Szemügyre vettük továbbá, hogy a szomszédsági hatásoknak van e kimutatható időbeli dinamikája a különböző régiókba, kontinenseken.

A globális Moran-féle I értékek azt mutatják, hogy a teljes időszakban gyenge, de szignifikáns térbeli függőség, pozitív területi autokorreláció jellemezte a globális kukoricaexportot. A térbeli függéség mértéke jelentősen ingadozott a vizsgált években, nem mutatott olyan trendet, ami magyarázható lenne a kukoricapiac radikális bővülésével. Ez az ingadozás azt is mutatja, hogy a térbeli függőség jelenléte aligha magyarázható kizárólag természeti adottságokkal, klimatikus viszonyok által meghatározott zónákkal. A természeti tényezők által alakított térbeli függőség esetében ugyanis jóval stabilabb időbeli dinamikát kellene tapasztalnunk. Mindezek alapján feltételezhetjük, hogy a térbeli függőség jelenléte részben gazdasági jelenségek, piaci folyamatok által meghatározott szomszédsági hatásoknak köszönhető. Érdemes kiemelni az 1997-1999 között végbemenő (tehát a piacbővülési időszakot megelőző), erőteljes autokorreláció csökkenést. A lokális szintű vizsgálatok tükrében kijelenthető, hogy ezt a csökkenést három folyamat okozta. Egyrészt, a kiemelkedően fontos kukoricaexportőr, 1996-ban még „egyeduralkodó” Egyesült Államok mellett megjelentek a dél-amerikai nagy kukoricaexportőrök (Argentína és Brazília) és kialakult egy jelentős dél-amerikai kukorica kereskedelmi gócpont. Másrészt, a korábban még jelentéktelen, pár országot érintő európai $\mathrm{HH}$ zóna kelet felé egyre nagyobb kiterjedésűvé, globális jelentőségű területi klaszterré vált. Harmadrészt, a BRICS-országcsoport „zónákon kívüli” tagjai (Dél-Afrikai Köztársaság, India Kína) exportbővülése szintén nagymértékben növelte a kukoricaexport térbeli szórtságát. Ráadásul, ezen országok körül 
nem alakultak ki HH szomszédsági kapcsolatok, tehát valószínűleg leginkább ez utóbbi folyamat hatott leginkább a térbeli függőség csökkenésére.

A lokális területi autokorreláció azt sugallja, hogy a vizsgált időszakban (a globális autokorreláció csökkenése ellenére) növekedett a „forró zónák” (HH klaszterek) száma és kiterjedése. A kukoricapiac radikális bővülése elsősorban helyi szinten, egy-egy térségre korlátozva idézte elő a térbeli függőség (és ennek hátterében feltételezhetően a szomszédsági kapcsolatok) erősödését. Eredményeink három $\mathrm{HH}$ területi klasztert azonosítottak a vizsgált időszakban: az észak-amerikai, a dél-amerikai és az európai klasztert. A vizsgált térségek közül leginkább Európában, azon belül is az egységes piacot alkotó EU-tagállamok körében játszanak kiemelt szerepet a szomszédsági kapcsolatok a kukoricaexport aktivitásban. Eredményeink az EU, mint egységes piacot, és szabadkereskedelmet biztosító intézmény szomszédsági kapcsolatokra gyakorolt pozitív hatását is igazolják. Másik oldalról az is látható, hogy a legnagyobb exportbővülést produkáló országok egy része (különösen India, Kína, Dél-Afrikai Köztársaság, és részben Oroszország) a saját térségükből „kiugró” szigeteket alkotnak, a környezetükben nem alakultak ki kiemelkedő exportot mutató, több országon átívelő zónák. Igaz, eredményeink szerint az itt felsorolt országok kukoricapiaci előretörése nem is rontotta a szomszédos országok exportpozícióit. Eredményeink arra utalnak, hogy a szomszédsági hatások kimutatható térbeli dinamikával is rendelkeznek, azaz a szomszédok korábbi exportteljesítménye hatással lehet a későbbi kukoricaexportra bizonyos országok és régiók esetében. Az autokorrelációs értékek időbeli változásai arra utalnak, hogy azok mögött valóban vannak szomszédsági hatások, az egyes HH és LL klasztertagok együtt mozgása nem magyarázható kizárólag hasonló földrajzi adottságokkal.

Eredményeink gyakorlati jelentősége, hogy felhívják a figyelmet a szabadkereskedelmi egyezmények és az egységes piac regionális jelentőségére. Az Európában tapasztalható folyamatok alátámasztják az EU-bővülés integrációs hatását, de hasonló szabadkereskedelmi hatások feltételezhetőek Észak- és Dél-Amerika esetében is. A szomszédsági kapcsolatok jelentős szerepet játszanak a közép- és kelet-európai térségben, ahol az országok egy jelentős része nem rendelkezik tengeri/kikötői kapcsolattal. Az európai klaszter keletre tolódása felvet olyan esetleges további kutatásokban vizsgálni érdemes kérdéseket a térségre vonatkozóan, mint a környezetvédelmi szempontok lehetséges erősebb érvényesülése a nyugati országoknál, valamint a mezőgazdasági tevékenység szándékos leépítése a kukorica termesztés alacsonyabb hozzáadott érték miatt. 

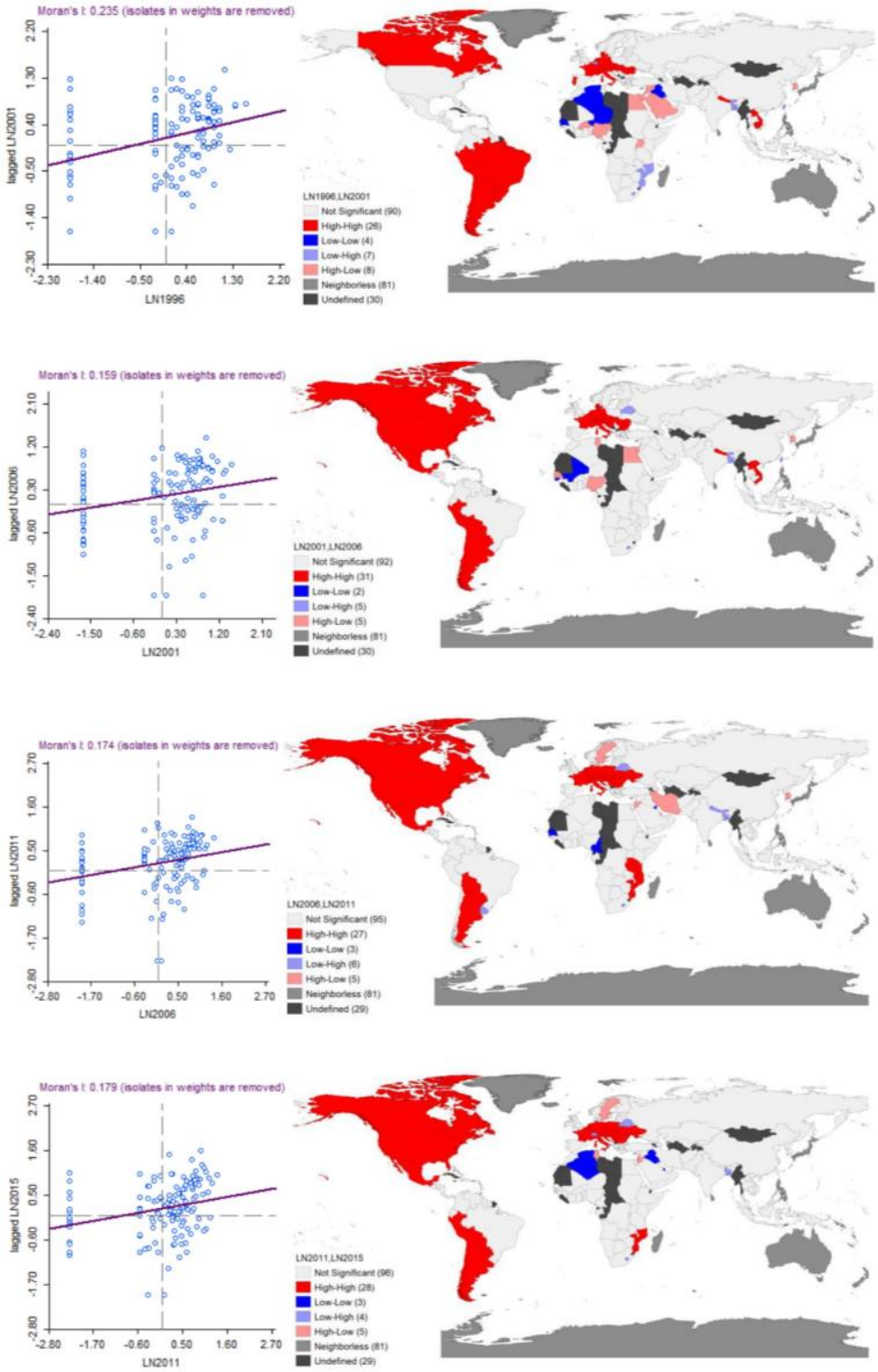

\section{4. ábra}

A kukoricaexport és ötéves időbeli késleltetésének autokorrelációja (1996-2015) (Figure 4 Autocorrelation of maize exports and their fiveyear time lag (1996-2015) 


\section{Köszönetnyilvánítás: A tanulmány az EFOP-16-2017-00018 azonosítószámú projekt támogatásával jött létre.}

\section{IRODALOMJEGYZÉK}

Ackerman, F., Wise, T. A., Gallagher, K. P., Ney, L., Flores, R. (2003). Free trade, corn, and the environment: Environmental impacts of US-Mexico corn trade under NAFTA. Global Development and Enviroment Institute, Working paper, Tufts University. Medford, USA DOI: $\underline{10.4337 / 9781848446045.00017}$

Allaire, G., Poméon, T., Maigné, E., Cahuzac, E., Simioni, M., Desejeux, Y. (2015). Territorial analysis of the diffusion of organic farming in France: Between heterogeneity and spatial dependence. Ecological Indicators, 59, 70-81. DOI: 10.1016/i.ecolind.2015.03.009

Anselin, L. (2010). Local Indicators of Spatial Association - LISA. Geographical Analysis, 27 (2), 93115. DOI: $10.1111 / j .1538-4632.1995 . t b 00338 . x$

Cheng, S., Song, L., LI, X. (2014). Evolution of spatial pattern of crude oil trade. Studies in Sociology of Science, 5 (1), 1. Link

Cliff, A. D., Ord, J. K. (1974). Spatial autocorrelation, London: Pion.

Combes, P. P., Overman, H. G. (2004). The spatial distribution of economic activities in the European Union. Handbook of regional and urban economics, 4, 2845-2909. DOI: $10.1016 / s 1574-$ 0080(04)80021-X

Csonka, A., Bareith, T., Gál, V.A. (2018a). Spatial distribution of the demand for CAP-measures to promote agroforestry: The Hungarian case. 14th Annual International Conference on Economics and Business, 10-12. May 2018. Sapientia Hungarian University of Transylvania, Csíkszereda/Miercurea Ciuc, Romania. pp. 59-68. Link

Csonka, A., Bareith, T., Gál, V. A. Fertő, I. (2018b). Spatial Pattern of CAP Measures Promoting Agroforestry in Hungary. AgBioForum, 21 (2), 127-134. Link

Csonka, A., Fertő, I. (2017). Spatial Dimension of Structural Changes in the Hungarian Hog Sector, Proceedings of 6th International Conference of Economic Sciences, 4-5. May. 2017. Kaposvár University, Kaposvár. pp. 11-20. Link

Csonka, A., Fertő, I. (2020). Structural change and agglomeration in the Hungarian pork industry. European Planning Studies, 28 (9), 1756-1770. DOI: 10.1080/09654313.2019.1687652

Csuvár, Á., Barna, R. (2020). Spatial illustration of indicators on the example of biomass potential for energy purposes in the Tabi district, Regional and Business Studies, 12 (1), 29-43. DOI: $\underline{10.33568 / r b s .2458}$

de la Mata, T., Llano-Verduras, C. (2011). Spatial pattern and domestic tourism: An econometric analysis using inter-regional monetary flows by type of journey. Papers in Regional Science, 91 (2), 437470. DOI: $10.1111 /$ j.1435-5957.2011.00376.X

Fujita, M., Krugman, P. R., Venables, A. (1999). The spatial economy: Cities, regions, and international trade. MIT press. DOI: $10.7551 /$ mitpress/6389.001.0001

Holmes, T. J., Lee, S. (2012). Economies of density versus natural advantage: Crop choice on the back forty. Review of Economics and Statistics, 94 (1), 1-19. DOI: 10.1162/rest a 00149

Ilbery, B., Maye, D. (2010). Clustering and the spatial distribution of organic farming in England and Wales. Area, 43 (1), 31-41. DOI: 10.1111/j.1475-4762.2010.00953.X

Isik, M. (2004). Environmental regulation and the spatial structure of the US dairy sector. American Journal of Agricultural Economics, 86 (4), 949-962. DOI: 10.1111/j.0002-9092.2004.00645.x

Lin, F., Sim, N. C. (2012). Death of distance and the distance puzzle. Economics Letters, 116 (2), 225228. DOI: 10.1016/j.econlet.2012.03.004 
Logan, J. (2005). Spatial thinking in social science, előadássorozat, Brown Univesity Letöltve: Link (Utolsó letöltés: 20/02/2020)

McWilliams, M., Moore, M. (2013). Agglomeration in agriculture: a quasi-experiment in the corn belt. In Heartland Environmental and Resource Economics Workshop. Link

Mulatu, A., Wossink, A. (2014). Environmental regulation and location of industrialized agricultural production in Europe. Land Economics, 90 (3), 509-537. DOI: 10.3368/le.90.3.509

Nemes Nagy, J. (2005). Regionális elemzési módszerek. Regionális tudományi tanulmányok, 11., ELTE Regionális Földrajzi Tanszék, MTA-ELTE Regionális Tudományi Kutatócsoport, Budapest. Link

Nene, G., Schoengold, K. (2019). Hog Production and Agglomeration Economies: The Case of US StateLevel Hog Production. Journal of Agricultural Economics, 5 (3), 663-672. Link

Neumann, K., Verburg, P. H., Stehfest, E., Müller, C. (2010). The yield gap of global grain production: A spatial analysis. Agricultural systems, 103 (5), 316-326. DOI: 10.1016/j.agsy.2010.02.004

OECD (2019). Crop production (indicator). (Utolsó letöltés: 26/09/2019)

Risgaard, M. L., Frederiksen, P., Kaltoft, P. (2007). Socio-cultural processes behind the differential distribution of organic farming in Denmark: a case study. Agriculture and Human Values, 24 (4), 445459. DOI: $10.1007 / s 10460-007-9092-y$

Schmidtner, E., Lippert, C., Engler, B., Haring, A. M., Aubacher, J., Dabbert, S. (2012). Spatial distribution of organic farming in Germany: does neighbourhood matter?. European Review of Agricultural Economics, 39 (4), 661-683. DOI: 10.1093/erae/jbr047

Schepf, R.D. (2007). US-Canada WTO Corn Trade Dispute. Congressional Research Service, Library of Congress.

Sweeney, S., Steigerwald, D. G., Davenport, F., Eakin, H. (2013). Mexican maize production: Evolving organizational and spatial structures since 1980. Applied Geography, 39, 78-92. DOI: 10.1016/j.apgeog.2012.12.005

Tiefelsdorf, M. (2002). The Saddlepoint Approximation of Moran's I's and Local Moran's I's Reference Distributions and Their Numerical Evaluation. Geographical Analysis 34 (3), 187-206. DOI: $\underline{10.1111 / j .1538-4632.2002 . t b 01084 . x}$

Tobler, W.R. (1970). A computer movie simulating urban grown in the Detroit region. Economic Geography 46, 234-240. DOI: $10.2307 / 143141$

UNSD (2017). Commodity Trade Database (COMTRADE). United Nations Statistical Division, New York. Elérhető: $\underline{\text { Link }}$

World Bank (2017). Commodity Trade Database (COMTRADE), Elérhető: World Bank’s World Integrated Trade Solution (WITS) software, Washington D.C. Elérhető: Link

Yang, W., Liu, Y. C., Mai, C. C. (2017). How did Japanese exports evolve from 1995 to 2014? A spatial econometric perspective. Japan and the World Economy, 41, 50-58. DOI: 10.1016/j.japwor.2016.12.002

Yilmazkuday, H. (2020). Welfare Implications of Solving the Distance Puzzle: Global Evidence from the Last Two Centuries. SSRN Electronic Journal, pp 34. DOI: 10.2139/ssrn.3533415

Yotov, V.Y. (2012). A simple solution to the distance puzzle in international trade, Economics Letters, 117 (3) 794-798, DOI: 10.1016/j.econlet.2012.08.032

Zahniser, S., Coyle, W. T. (2004). US-Mexico corn trade during the NAFTA era: new twists to an old story. US Department of Agriculture, Economic Research Service.

Zhang, L., Wang, J., Wen, H., Fu, Z., Li, X. (2016). Operating performance, industry agglomeration and its spatial characteristics of Chinese photovoltaic industry. Renewable and Sustainable Energy Reviews 65, 373-386. DOI: 10.1016/j.rser.2016.07.010

(C) Copyright 2021 by the authors. This is an open access article under the terms

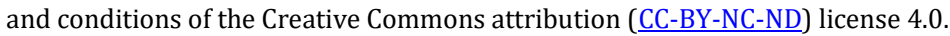

